\title{
Abrupt cold events in the North Atlantic Ocean in a transient Holocene simulation
}

\author{
Andrea Klus ${ }^{1}$, Matthias Prange ${ }^{1}$, Vidya Varma ${ }^{2}$, Louis Bruno Tremblay ${ }^{3}$, and Michael Schulz ${ }^{1}$ \\ ${ }^{1}$ MARUM - Center for Marine Environmental Sciences and Faculty of Geosciences, \\ University of Bremen, Bremen, Germany \\ ${ }^{2}$ National Institute of Water and Atmospheric Research, Wellington, New Zealand \\ ${ }^{3}$ Department of Atmospheric and Oceanic Sciences, McGill University, Montreal, Canada
}

Correspondence: Andrea Klus (aklus@marum.de)

Received: 25 August 2017 - Discussion started: 25 September 2017

Accepted: 16 July 2018 - Published: 14 August 2018

\begin{abstract}
Abrupt cold events have been detected in numerous North Atlantic climate records from the Holocene. Several mechanisms have been discussed as possible triggers for these climate shifts persisting decades to centuries. Here, we describe two abrupt cold events that occurred during an orbitally forced transient Holocene simulation using the Community Climate System Model version 3. Both events occurred during the late Holocene (4305-4267 BP and 3046-3018 BP for event 1 and event 2, respectively). They were characterized by substantial surface cooling $(-2.3$ and $-1.8^{\circ} \mathrm{C}$, respectively) and freshening ( -0.6 and $-0.5 \mathrm{PSU}$, respectively) as well as severe sea ice advance east of Newfoundland and south of Greenland, reaching as far as the Iceland Basin in the northeastern Atlantic at the climaxes of the cold events. Convection and deep-water formation in the northwestern Atlantic collapsed during the events, while the Atlantic Meridional Overturning Circulation was not substantially affected (weakening by only about $10 \%$ and $5 \%$, respectively). The events were triggered by prolonged phases of a positive North Atlantic Oscillation that caused substantial changes in the subpolar ocean circulation and associated freshwater transports, resulting in a weakening of the subpolar gyre. Our results suggest a possible mechanism by which abrupt cold events in the North Atlantic region may be triggered by internal climate variability without the need of an external (e.g., solar or volcanic) forcing.
\end{abstract}

\section{Introduction}

Holocene climate variability in the North Atlantic at different timescales has been discussed extensively during the past decades (e.g., Kleppin et al., 2015; Drijfhout et al., 2013; Hall et al., 2004; Schulz and Paul, 2002; Hall and Stouffer, 2001; Bond et al., 1997, 2001; O’Brien et al., 1995; Wanner et al., 2001, 2011). North Atlantic cold events can be accompanied by sea ice drift from the Nordic Seas and the Labrador Sea towards the Iceland Basin as well as by changes in the Atlantic Meridional Overturning Circulation (AMOC). The sea ice proxy $\mathrm{IP}_{25}$ (Belt et al., 2007) and diatom-based sea surface temperature (SST) reconstructions from a sediment core north of Iceland show evidence for abrupt sea-ice and climate changes (Massé et al., 2008). During the Little Ice Age (AD 1300-1850) several cold intervals at multi-decadal timescales have been identified in the Northern Hemispheric SST records (Crowley and Lowery, 2000), associated with the Dalton (AD 1790-1820) and the Late Maunder solar minima (AD 1675-1715). Wanner et al. (1995) showed that the Late Maunder Minimum has been a relatively cool and dry period of approximately 40 years with a larger-than-normal sea ice extent. However, not all North Atlantic cold phases during the Holocene are related to external forcing. For instance, Camenisch et al. (2016) report that the 1430s has been one of the coldest decades during the last millennium in northwestern and central Europe with a stronger-than-usual seasonal cycle in temperature neither related to anomalous solar nor volcanic activity.

Several mechanisms for the development of abrupt cold events in the North Atlantic have been discussed (e.g., Crow- 
ley, 2000; Alley, 2005). These include anomalous input of freshwater (Hawkins et al., 2011; Rahmstorf, 1996), volcanic activity (Sigl et al., 2015), solar forcing (Jiang et al., 2005; Steinhilber et al., 2009; Gray et al., 2010), or a combination of these factors (Büntgen et al., 2011; Jongma et al., 2007). Other causes for abrupt events that have been considered are associated with internal atmosphere-ocean variability (Hall and Stouffer, 2001), sea ice transport (Wanner et al., 2008, and references therein), and sea-ice-atmosphere interactions (Lehner et al., 2013; Li et al., 2005, 2010). An expansion of sea ice could trigger a sudden and extensive change in air temperature by switching off the heat exchange between ocean and atmosphere (Kleppin et al., 2015). Furthermore, an abrupt climate shift can be forced by a "Great Salinity Anomaly" (GSA) - a term coined by Dickson et al. (1988) - describing an event with a major input of freshwater to the Nordic Seas in the 1960s and 1970s with a freshening of $\sim 0.3 \mathrm{PSU}$ and a cooling of $1.5^{\circ} \mathrm{C}$ off the central Greenland coast (Dickson et al., 1988; Häkkinen, 1999) impacting the AMOC (Ionita et al., 2016). Hall and Stouffer (2001) described a similar event associated with an intensification of the East Greenland Current triggered by a high pressure anomaly centered over the Barents Sea that lasted $\sim 40$ years.

Moreover, internal variability such as a positive phase of the North Atlantic Oscillation (NAO) can lead to a tripolar SST pattern in the North Atlantic (Deser et al., 2010; Hurrell et al., 2013). The surface above the subpolar gyre (SPG) loses energy while the mid-latitudes gain energy as a result of the associated wind anomalies. The duration of the positive NAO phase is crucial for the response of the ocean (Lohmann et al., 2009; Visbeck et al., 2003). During a short positive NAO phase the SPG strengthens due to fast processes associated with surface fluxes, while it weakens if the phase continues over a longer period because of slow processes (e.g., transport of saline water or freshwater). To assess potential predictability of the NAO and to understand its interaction with the ocean, documentation of the past variability is required. Commonly used single proxy-based NAO reconstructions have severe shortcomings since regional teleconnections can be nonstationary (e.g., Raible et al., 2014; Schmutz et al., 2000). Therefore, a multi-proxy NAO reconstruction as presented by Ortega et al. (2015) can be helpful to adequately represent not just one but multiple typical NAO-related patterns, for example, in temperature and precipitation.

So far, our understanding of climate variability on multidecadal to millennial timescales is limited and cannot explain if and to what extent specific regions would be affected and whether rapid cold events are coupled to a substantial weakening of the AMOC. The understanding of multi-decadal cold events and their triggers will not only lead to a better understanding of paleoclimatic aspects but could potentially also improve predictions of climate change.

In the following, we study two spontaneous cold events in the northern North Atlantic and the Nordic Seas detected

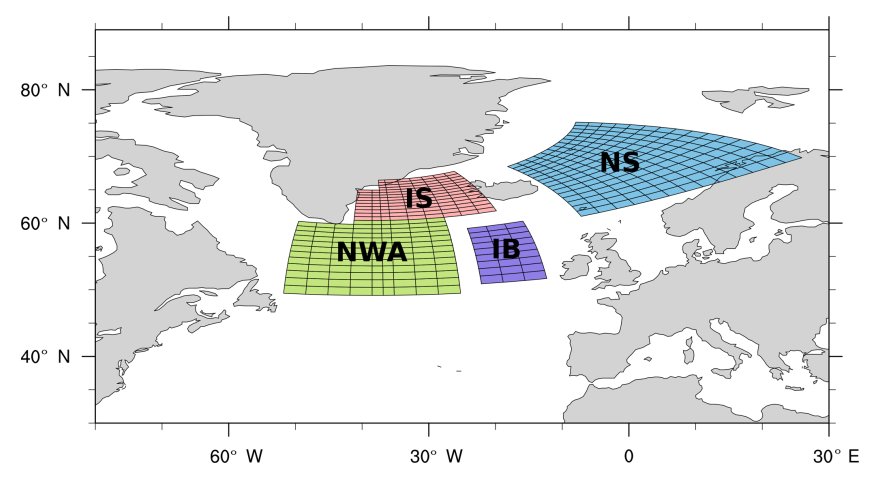

Figure 1. Areas of investigation: northwest Atlantic (NWA) in green, Irminger Sea (IS) in pink, Iceland Basin (IB) in purple, and Nordic Seas (NS) in blue.

in a transient Holocene simulation with the Community Climate System Model version 3 (Varma et al., 2016). Focusing on multi-decadal timescales we aim at improving our understanding of the mechanisms and feedbacks associated with Holocene cold events and their complex spatiotemporal pattern.

\section{Model description and experimental design}

A low-resolution transient simulation of Holocene climate change has been performed with the comprehensive Community Climate System Model version 3 (CCSM3; Varma et al., 2016). Detailed information about the model including the source code is available at http://www.cesm.ucar. edu/models/ccsm3.0/ (last access: 23 August 2017). The fully coupled global climate model consists of four components representing the atmosphere, ocean, land, and sea ice (Collins et al., 2006a). The atmospheric component of the CCSM3 is the Community Atmosphere Model version 3 (CAM3; Collins et al., 2006b). In this model setup we used the T31 resolution ( $3.75^{\circ}$ transform grid) with 26 unevenly distributed layers in the vertical (Yeager et al., 2006). The ocean component is the Parallel Ocean Program (POP; Smith and Gent, 2004) which has a nominal resolution of $3^{\circ}$ with a refined meridional resolution of $0.9^{\circ}$ around the Equator and 25 vertical levels. The sea ice component of CCSM3 is the Community Sea Ice Model version 5 (CSIM5; Briegleb et al., 2004), which runs on the same horizontal grid as POP.

The model run has been performed at the North-German Supercomputing Alliance (HLRN2) in Hanover. From a preindustrial equilibrium simulation (Merkel et al., 2010), the model was integrated for 400 years with orbital forcing conditions representing 9000 years BP (before present) to reach a new quasi-equilibrium. Afterwards, a non-accelerated transient Holocene simulation was carried out by forcing the model with changing orbital parameters until the year 2000 BP (Varma et al., 2016). Greenhouse gas concentrations and aerosol and ozone distributions were kept 
at pre-industrial values $\left(\mathrm{CH}_{4}=760 \mathrm{ppbv}, \mathrm{CO}_{2}=280 \mathrm{ppm}\right.$, $\mathrm{N}_{2} \mathrm{O}=270$ ppbv; Braconnot et al., 2007). Variations in solar irradiance and changes in the continental ice sheets are ignored. Variations in the orbital parameters were therefore the only external forcing in this model simulation. Surface freshwater fluxes (e.g., precipitation, evaporation, runoff, and sea ice melting and formation) are represented through virtual salinity fluxes (Prange and Gerdes, 2006) with a reference salinity of 34.7 (equal to the global average salinity). The model results presented below are all yearly mean values, unless otherwise specified. The definitions of oceanic regions used throughout the paper are shown in Fig. 1.

\section{Results}

\subsection{General state description}

In the following, we discuss two abrupt cold events in the North Atlantic that are evident in a 7000-year-long Holocene model run (Fig. 2a-e) and lasted 39 years (4305-4267 BP) and 29 years (3046-3018 BP), respectively. We define a cold event as a time period when the SST falls below the $2 \sigma$ interval in the northwest Atlantic (NWA, Fig. 1) for at least 20 years. The time span 4000-3201 BP is used here to describe the "normal conditions" (reference state). Both the SST and the sea surface salinity (SSS) in the NWA show a negative trend over the Holocene with a mean of $3.9^{\circ} \mathrm{C}$ and 34.1 PSU in the reference time interval (Fig. 2a-b). Except for the abrupt cold events, the Iceland Basin is mostly ice free (Fig. 2c). The NWA features a low annual mean sea ice concentration of $6.1 \%$ with a slightly positive trend during the Holocene, in line with the decreasing annual SSS and SST. Deep-water formation takes place in the NWA south of Greenland, the Irminger Sea, and in the Nordic Seas (Fig. 1) around $75^{\circ} \mathrm{N}, 5^{\circ} \mathrm{W}$. The averaged mixed-layer depth is $121 \mathrm{~m}$ in the NWA and does not exhibit a trend over time (Fig. 2d). The areas of deep-water formation are ice free while the Baffin Bay, Labrador coastline, and the northern Nordic Seas are partly ice covered (not shown). The maximum AMOC streamfunction calculated north of $30^{\circ} \mathrm{N}$ and below $500 \mathrm{~m}$ water depth amounts to $13.5 \mathrm{~Sv}$ on average and varies between 9.4 and $17.7 \mathrm{~Sv}$ with a negative trend during the first $\sim 1000$ years of the simulation $(9-8 \mathrm{kaBP})$ and no trend afterwards (Fig. 2e). Under normal conditions the annual mean sea-level pressure difference between Iceland $(1006 \mathrm{hPa})$ and the Azores $(1022 \mathrm{hPa})$ is equal to $16 \mathrm{hPa}$ (Fig. 3a).

\subsection{Anomalies during cold events}

Two cold events are evident in the 7000-year-long time series: event 1 occurs between 4305 and 4267 BP (Fig. 4) and event 2 occurs between 3046 and 3018 BP (Fig. 5). During these cold events the NWA undergoes a substantial reorganization of mixed-layer depth, sea ice, SST, and SSS (Fig. 6a- h). In the following, all anomalies are described in comparison to the "normal conditions" of 4000-3201 BP (reference interval). During events 1 and 2 the mixed-layer depths in the NWA, the Irminger Sea, and the northern Nordic Seas decrease while the mixed-layer depth northeast of Iceland increases, indicating a southward shift of convection (Fig. 6ab). The sea ice concentration in the Baffin Bay, the NWA, and the northern Nordic Seas increases whereas the sea ice concentration close to Iceland declines. In the NWA a maximum sea ice concentration of $37 \%$ is reached in $4294 \mathrm{BP}$ and $26 \%$ in 3024 BP (Figs. 4a, c, 5a, c, 6c-d). This corresponds to anomalies of $16.3 \sigma$ and $10.5 \sigma$ during event 1 and 2 , respectively, for the NWA in comparison to the time span 4000-3201 BP. During some years, sea ice reaches the Iceland Basin with a maximum annual sea ice concentration of $4 \%$ in year $4278 \mathrm{BP}$ and $0.6 \%$ in year $3021 \mathrm{BP}$. While the Atlantic does not show a significant change in SST or SSS south of $30^{\circ} \mathrm{N}$, the cold events result in a cooling of $-2.3^{\circ} \mathrm{C}$ during event $1\left(-1.8^{\circ} \mathrm{C}\right.$ during event 2$)$ and a freshening of $-0.6 \mathrm{PSU}$ during event 1 ( $-0.5 \mathrm{PSU}$ during event 2 ) averaged over the NWA (Figs. 2a-b, 6e-h). In the northern Nordic Seas, SST and SSS decrease, whereas the sea ice concentration increases (event 1 : cooling of $-1.8^{\circ} \mathrm{C}$, freshening of $-1.0 \mathrm{PSU}$, rise in sea ice concentration of $29 \%$; event 2: cooling of $-1.1^{\circ} \mathrm{C}$, freshening of $-0.7 \mathrm{PSU}$, rise in sea ice concentration of $15 \%$; Fig. 6c-h). However, an increase in both SST and SSS and a decline in sea ice concentration is found northeast of Iceland (event 1: warming of $1.6^{\circ} \mathrm{C}$, rise of $0.7 \mathrm{PSU}$, decline of $-15 \%$ in sea ice concentration; event 2: warming of $2.0^{\circ} \mathrm{C}$, rise of $0.8 \mathrm{PSU}$, decline of $-11 \%$ in sea ice concentration).

The AMOC time series shows a tendency to lower values during the first event (difference of $-1.2 \mathrm{~Sv}$ ), but still remains above $10 \mathrm{~Sv}$ (Figs. 2, 4). During the second event, the AMOC does not show a significant drop (Figs. 2, 5), although the mixed-layer depth in the NWA decreases during this period. Some solid and liquid freshwater transports in the polar and subpolar region undergo a transition as well. In particular, the southward transport of liquid freshwater of the East Greenland Current through the Denmark Strait intensifies by $648 \mathrm{~km}^{3} \mathrm{yr}^{-1}$ during event 1 . During the second event the freshwater transport in the NWA also increases but this time the pathway is different, i.e., the increase is observed through the Canadian Arctic Archipelago rather than through the Denmark Strait. The freshwater transport in the East Greenland Current does not intensify significantly $\left(220 \mathrm{~km}^{3} \mathrm{yr}^{-1}\right)$ but the export of liquid freshwater through the Canadian Arctic Archipelago increases by $476 \mathrm{~km}^{3} \mathrm{yr}^{-1}$ (Fig. 7b; event 1: $106 \mathrm{~km}^{3} \mathrm{yr}^{-1}$ ).

During event 1 (event 2) a weakening of the SLP above Greenland and Iceland of up to $-0.7 \mathrm{hPa}(-2.8 \mathrm{hPa})$ is present indicating a positive NAO-like pattern (Fig. 3b-c). The changes in SLP are even more apparent during wintertime (DJF). During event 1 anomalies of up to $+4.4 \mathrm{hPa}$ above Europe and the North Atlantic between 35 and $60^{\circ} \mathrm{N}$ 
(a)

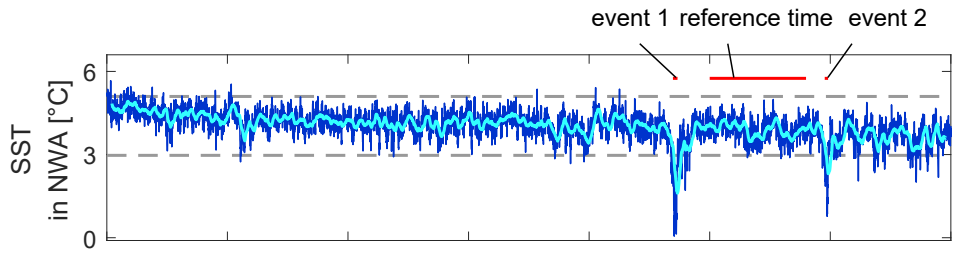

(b)

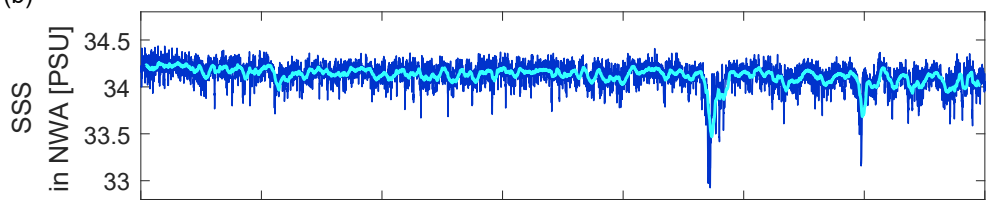

(c)

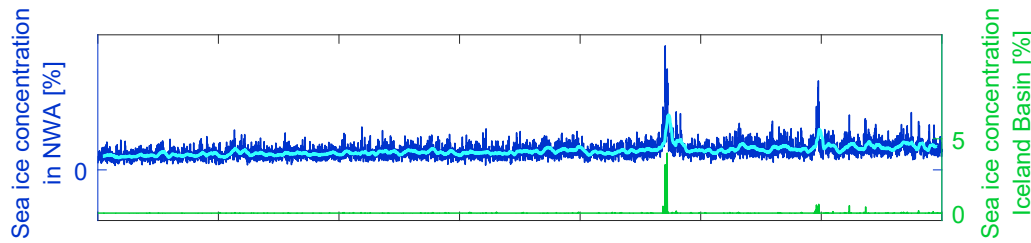

(d)

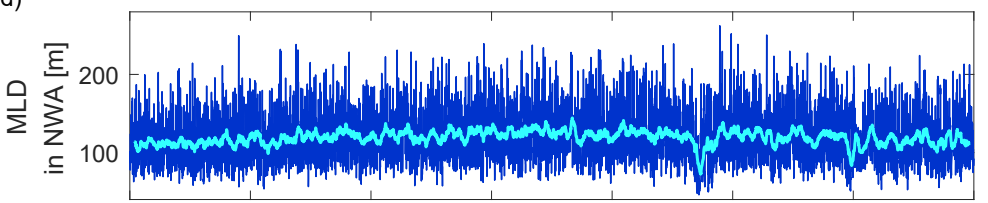

(e)

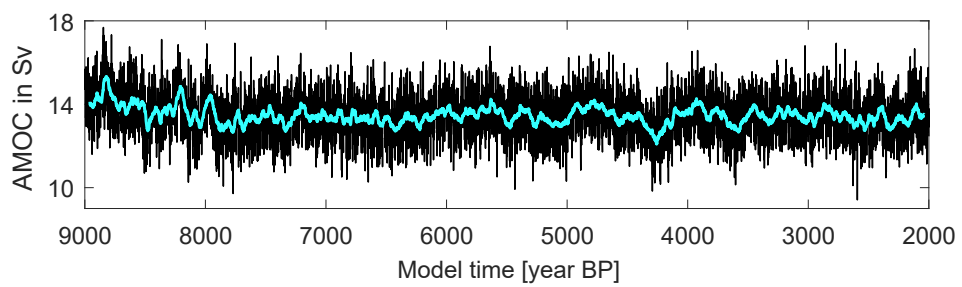

Figure 2. Time series of the annual mean (a) sea surface temperature (SST; in ${ }^{\circ} \mathrm{C}$ ) in the NWA, (b) sea surface salinity (SSS; in PSU) in the NWA, (c) sea ice concentration in \% in the Iceland Basin (green) and in the northwest Atlantic (NWA, blue), (d) mixed-layer depth (MLD; in $\mathrm{m}$ ) in the NWA, and (e) AMOC calculated as the maximum of the streamfunction in the Atlantic north of $30^{\circ} \mathrm{N}$ and below $500 \mathrm{~m}$ water depth. The respective 40 -year-running means are indicated by the light blue lines. The dashed gray line indicates the 2 -standard-deviation range for the SST. The red lines indicate the time spans for the reference time, event 1 , and event 2.

and $-3.2 \mathrm{hPa}$ above Greenland and Iceland occur $(+5.4$ and $-4.2 \mathrm{hPa}$ during event 2; not shown). The NAO, defined as the leading mode (principal component) of variability in the SLP, is in a positive phase during winter (DJF) with SLP anomalies above Iceland (the Azores) exceeding the $2 \sigma$ interval during the two cold events (Fig. 8). We checked if and for how long the NAO exceeds the $2 \sigma$ interval during the rest of the Holocene (not shown). During spring (MAM) the NAO only exceeds the $2 \sigma$ interval for more than 10 years during the second cold event. Apart from the cold events, the winter (DJF) leading principal component exceeds the $2 \sigma$ interval only once for more than 10 years (7874-7861 BP). During this 14-year interval SST and SSS show a drop towards lower values in the NWA with mean anomalies of $-0.3{ }^{\circ} \mathrm{C}$ and
$-0.08 \mathrm{PSU}$, respectively (maximum anomalies of $-0.7^{\circ} \mathrm{C}$ and -0.13 PSU; Fig. 2).

\subsection{Development prior to the events}

The SLP pattern already changes prior to the events, which can be seen in the NAO time series (Fig. 8a, c; the leading principal component was calculated from the SLP in the Atlantic sector north of $35^{\circ} \mathrm{N}$ ). This behavior is most prominent in winter (DJF) for the first event and in spring (MAM) for the second event. The NAO index starts to increase towards a positive phase around $4320 \mathrm{BP}(\sim 15$ years prior to event 1$)$ for the first event and around $3070 \mathrm{BP}(\sim 24$ years prior to event 2) for the second event while the mixed-layer depth in the NWA does not decrease until years 4302 and 3052 BP, 
(a)

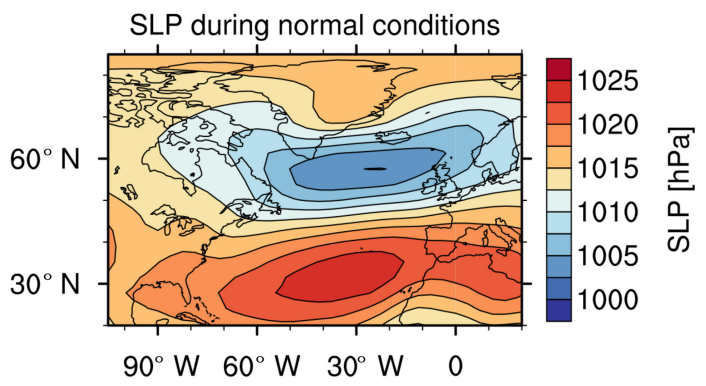

(b)

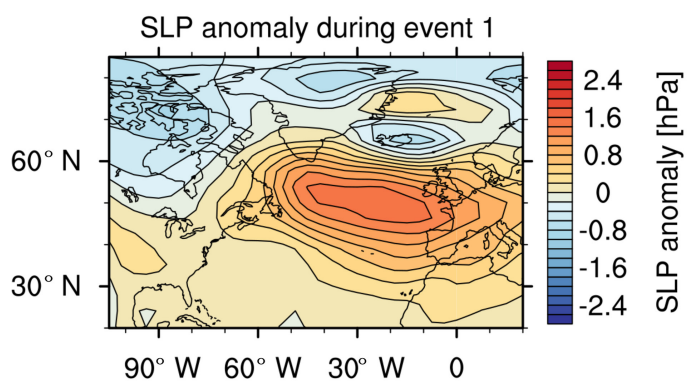

(c)

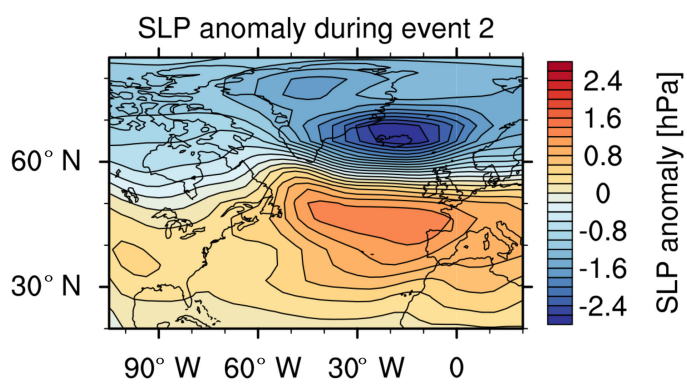

Figure 3. (a) Sea-level pressure during normal conditions (4000$3201 \mathrm{BP}$ ), sea-level pressure difference during (b) event 1 (4305$4267 \mathrm{BP})$, and (c) event 2 (3046-3018 BP).

respectively (Fig. 8b, d). Most of the other ocean variables react more slowly with an almost linear trend (Figs. 4-5) and the following maximum anomaly.

Shortly prior to, during, and after the events the SST and other variables show a quasi-oscillatory behavior, especially during event 1 (Figs. 4, 5). A frequency analysis showed that the period of the oscillations of the SST in the NWA is 20 years around event 1 and 14 years around event 2 (not shown).

\section{Discussion}

Given the previous evaluation that the change in the SLP associated with a positive trend in NAO happens prior to the change in the ocean variables suggests that the stochastic nature of the atmospheric variability is the trigger for both events. The change in SLP prior to the events is associated with changes in the wind, e.g., the westerlies strengthen over the subpolar North Atlantic, and southwestward and north- eastward wind anomalies occur between Iceland and Greenland (event 1) and between Scotland and Iceland (event 2). This leads to a change in ocean circulation and freshwater fluxes as well as in sea ice concentration and SST and SSS patterns (Figs. 6-7, 9).

\subsection{SST anomaly pattern and changes in ocean circulation}

A tripolar SST pattern in the North Atlantic can result from wind fields associated with a positive phase of the NAO (Deser et al., 2010; Hurrell et al., 2013). Our SLP difference (Fig. 3b-c) as well as SST difference patterns (Fig. 6ef) show similarities with this, while the range of difference is much broader in our case (up to $4^{\circ} \mathrm{C}$ SST difference in our study compared to $0.5^{\circ} \mathrm{C}$ in Deser et al., 2010). Deser et al. (2010) concluded that the NAO-related SST anomaly pattern is mainly driven by turbulent energy flux anomalies in the North Atlantic. The ocean loses energy above the SPG due to strengthened westerlies and gains energy in the midlatitudes due to weakened wind. Lohmann et al. (2009) show a strengthened and cooled SPG due to a short positive NAO phase, but after $\sim 10$ years it becomes warmer and weaker, and it becomes weaker due to a negative NAO phase. They concluded that this was the result of a highly nonlinear response of the circulation in the North Atlantic to atmospheric forcing. In our study, the westerlies strengthen as well and the ocean loses heat above the SPG. A decreased density can be seen in the center of the SPG due to a cooling and freshening (Fig. 6e-h) as well as a weakening of the SPG strength (Fig. 9), in a manner similar to the bistable behavior of the SPG suggested by Levermann and Born (2007). The advection of salty and warm water from the south into the SPG is reduced resulting in higher SSS at $\sim 40^{\circ} \mathrm{N}$ and lower SSS in the SPG (Fig. 9). A weakened SPG (Fig. 9) favors the cold and fresh water to stay in the SPG and the salty water in the Nordic Seas and south of the SPG. As a consequence the density at the surface is decreasing and the density profile of the water column has a higher stability. The water in the NWA becomes so fresh that deep convection is disturbed (Figs. 2, 4-6). In contrast to a temperature anomaly in the NWA of $-1.5^{\circ} \mathrm{C}$ as reported in Lohmann et al. (2009), we found a SST difference of up to $-4^{\circ} \mathrm{C}$, resulting in SST in the area of deep-water formation close to the freezing point. Therefore sea ice is less likely to melt and the high sea ice concentration hampers the interaction between ocean and atmosphere further reducing the surface heat loss of the ocean.

In the Nordic Seas the transport in the top $100 \mathrm{~m}$ from north and south towards $\sim 75^{\circ} \mathrm{N}$ (where deep convection takes place) becomes stronger. The southern Nordic Seas experience a cyclonic difference in ocean circulation leading to a saltier sea surface, while the northern Nordic Seas experience an anticyclonic difference associated with a freshening (Fig. 9). During event 2 the changes in ocean circulation and wind increase the transport of sea ice from the Cana- 
(a)

(b)

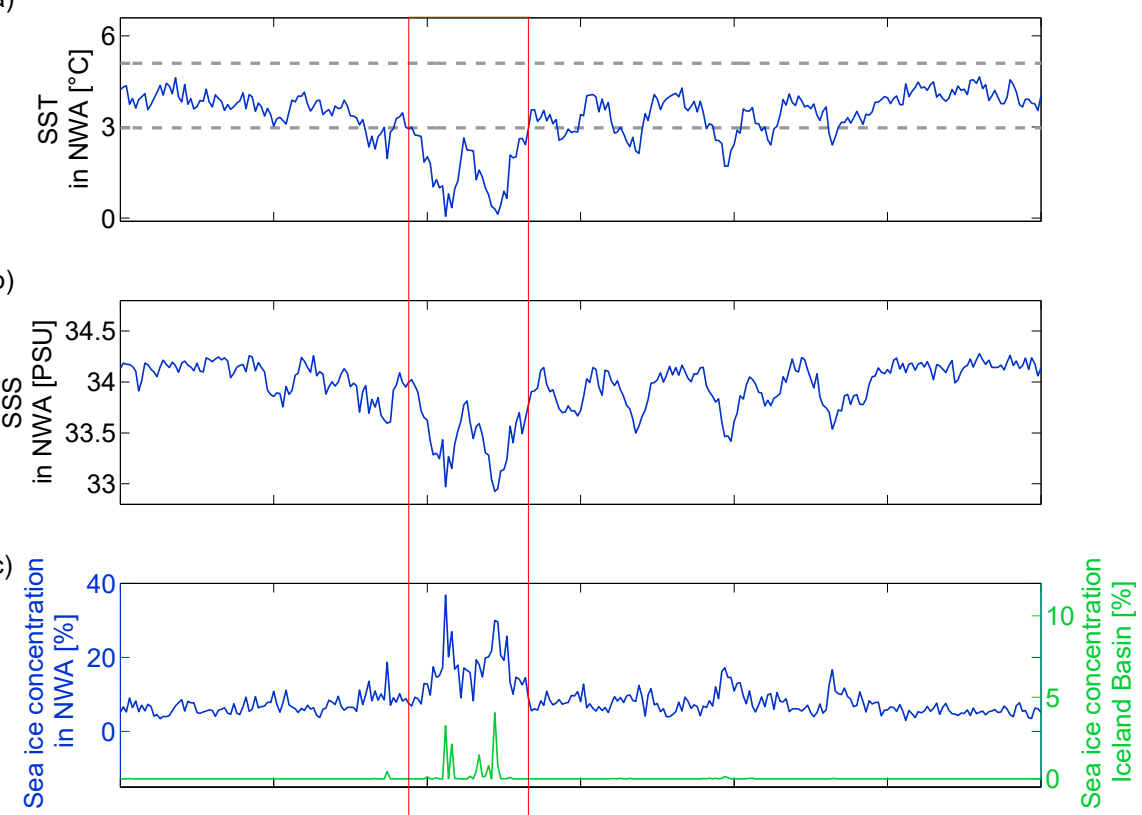

(d)

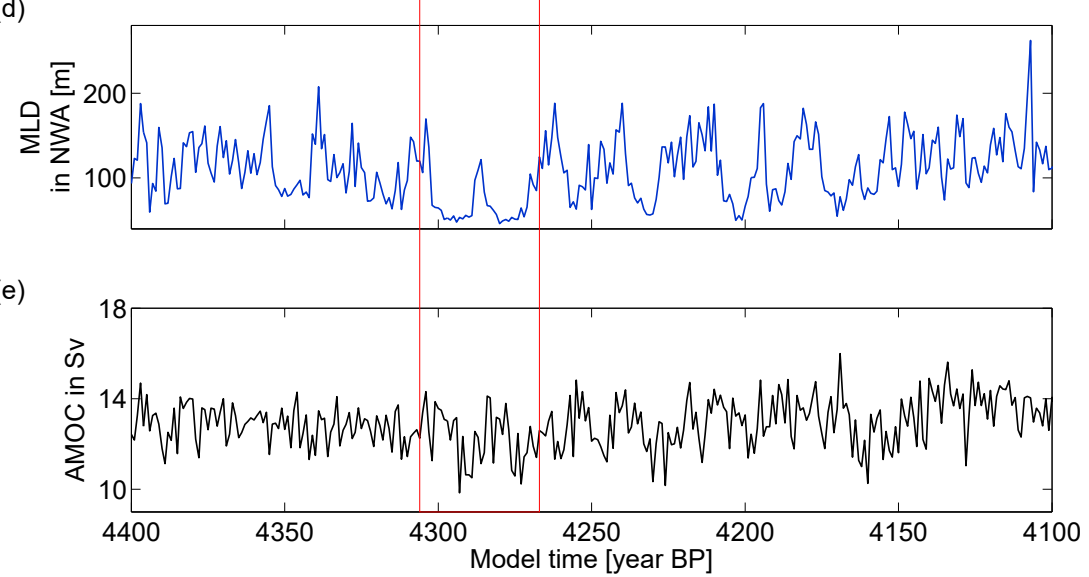

Figure 4. Zoom in on event 1. Same fields as in Fig. 2. The red box indicates the time span of the first event.

dian Shelf and Baffin Bay to the area of deep convection in the NWA. Other studies revealed that a SST anomaly pattern similar to our study can force a positive NAO phase (e.g., Czaja and Frankignoul, 2002; Frankignoul and Gastineau, 2015; Gastineau and Frankignoul, 2014). This would produce a positive feedback where the positive NAO triggers such a SST anomaly pattern and vice versa, leading the cold climate state to maintain for decades.

\subsection{Increase of freshwater transports}

The mean liquid freshwater transports (reference salinity of 34.7 PSU) through the Denmark Strait and the Canadian Arctic Archipelago is equal to -3924 and $-2613 \mathrm{~km}^{3} \mathrm{yr}^{-1}$, respectively, (negative values refer to southward transports), in accordance with published estimates of -4762 to
$-2712 \mathrm{~km}^{3} \mathrm{yr}^{-1}$ and -3200 to $-920 \mathrm{~km}^{3} \mathrm{yr}^{-1}$, respectively (Aagaard and Carmack, 1989; Dickson et al., 2007; Jahn et al., 2010; Karcher et al., 2005; Oka et al., 2006; Prange and Gerdes, 2006). Prior to and during the events the freshwater fluxes through the Denmark Strait and the Canadian Arctic Archipelago are intensified by changes in the surface wind. Southwestward wind anomalies along the east Greenland coast push more solid (Kwok, 2000) and liquid freshwater through the Denmark Strait (event 1: liquid freshwater flux difference of $-648 \mathrm{~km}^{3} \mathrm{yr}^{-1}$ after $\sim 4320 \mathrm{BP}$; Fig. 7a). These findings have similarities to the climate anomaly that lasted $\sim 40$ years in the SPG, discussed in Hall and Stouffer (2001). They found a strong intensification of the East Greenland Current related to a southwestward wind anomaly at the east coast of Greenland due to a high-pressure anomaly over Greenland and the Barents Sea. The SLP and wind 
(a)

(b)
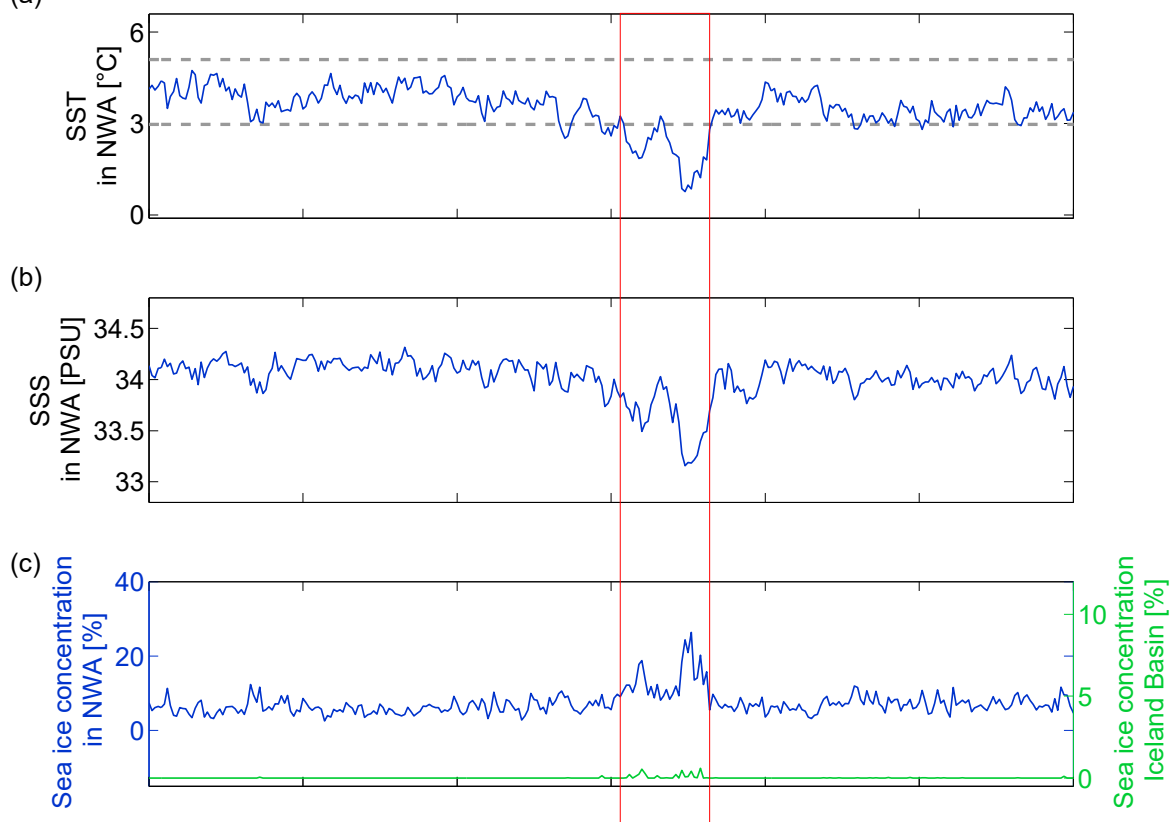

(d)

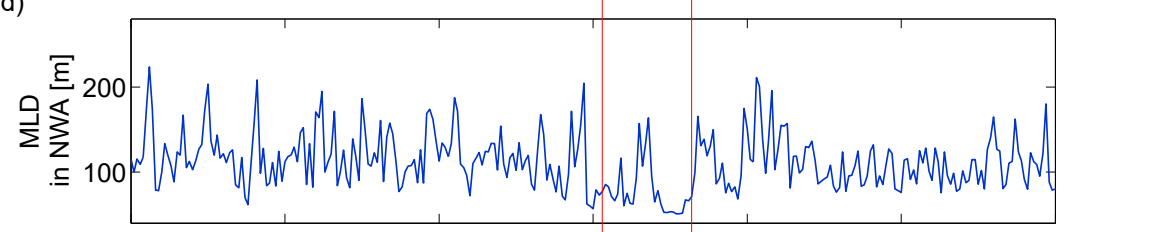

(e)

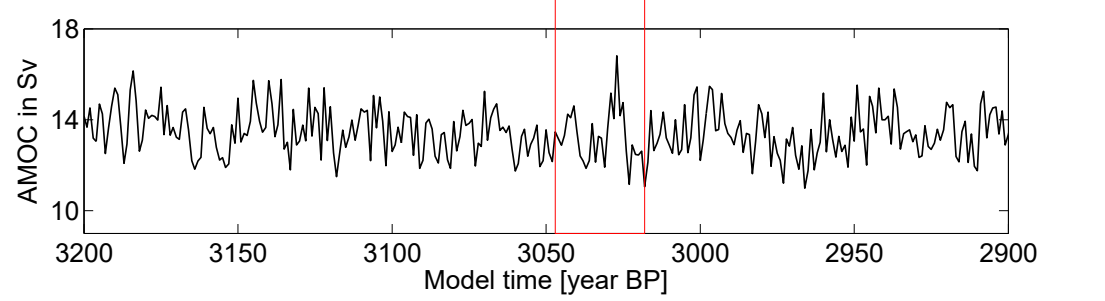

Figure 5. Zoom in on event 2. Same fields as in Fig. 2. The red box indicates the time span of the second event.

anomaly in their study show some differences to ours. In their study, the wind anomaly along the Greenland coast plays the most important role, while in our study the strengthening of freshwater transport through the Denmark Strait indicates that the intensified and northward-shifted Icelandic Low is more relevant for triggering the cold event. While Hall and Stouffer (2001) found the largest SSS anomaly of $\sim-1$ PSU close to the east and southeast coast of Greenland, in our study the largest negative difference of up to -1.6 PSU can be seen in the northern Nordic Seas and the North Atlantic at around $48^{\circ} \mathrm{N}$ (during event 2 the largest negative (positive) difference is about $-1.0 \mathrm{PSU}$ (1.4 PSU)). This is substantially more than during the Great Salinity Anomaly of the $1960 \mathrm{~s}$ and 1970s with a freshening of about 0.2 to $0.3 \mathrm{PSU}$ and a cooling of 1 to $1.5^{\circ} \mathrm{C}$ off the central Greenland coast. The salinity in the southern Nordic Seas and the
North Atlantic at about $40^{\circ} \mathrm{N}$ rises up to 1.6 PSU during the first event.

A major reason for the difference in the patterns is the change in ocean circulation found in our results. Combining the change in ocean circulation along with the SST, SSS, and sea ice anomalies (Fig. 6e-h) it can be stated that a stronger exchange between the North Atlantic and the Nordic Seas took place transporting more fresh and cold water out of Denmark Strait, especially during the first event. In contrast to the first event the anomalous isobars in Baffin Bay are aligned in the northwest-to-southeast direction during the second event (Fig. 3), leading to a southeastward wind anomaly. This way the Canadian Arctic Archipelago carries more freshwater (Fig. 7b) from the Arctic towards the NWA. The resulting SSS pattern is very similar to the first event and just differs in magnitude (Fig. 6g-h). The increased transports through the 
(a)

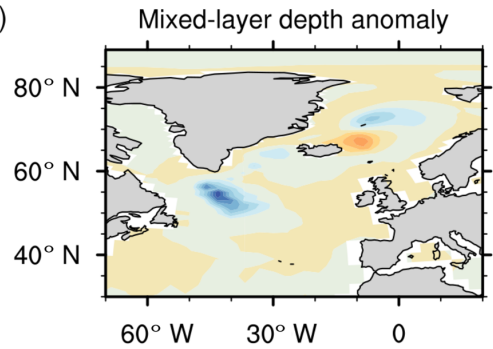

(c)

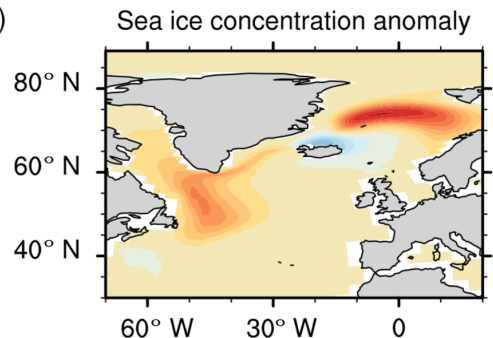

(e)

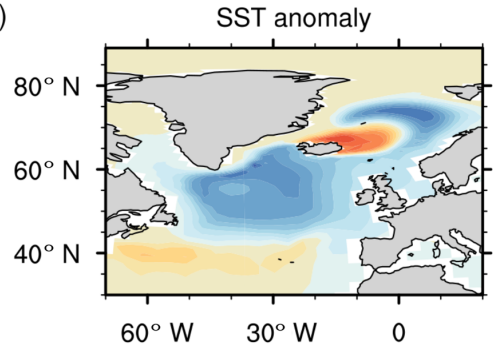

(g)

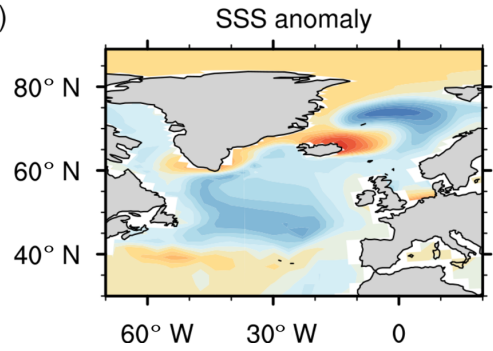

(b)

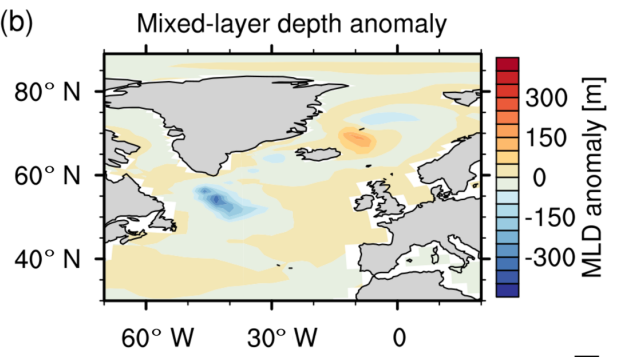

(d)

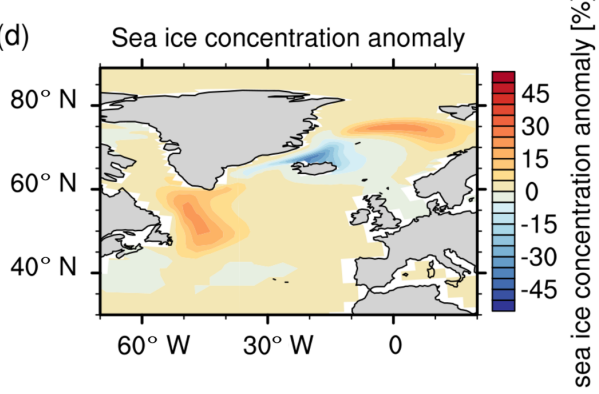

(f)

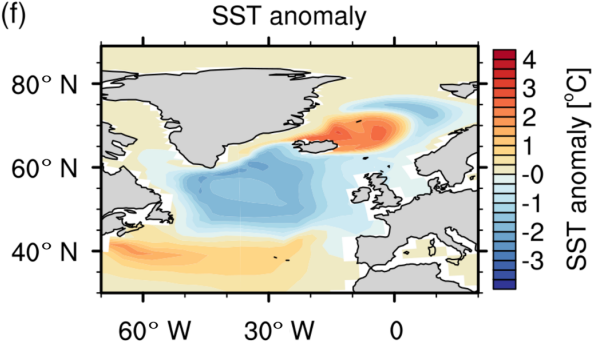

(h)

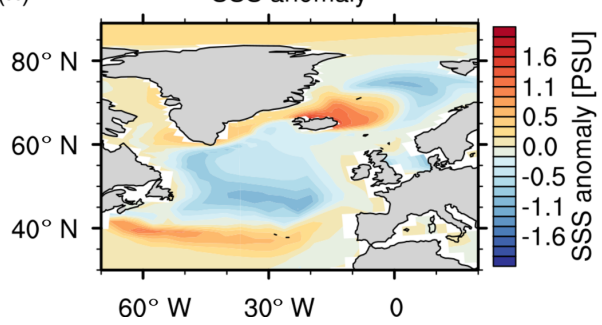

Figure 6. Difference maps for event 1 (left column; 4305-4267 BP) and event 2 (right column; 3046-3018 BP) of mixed-layer depth (m; a, b), sea ice concentration $(\% ; \mathbf{c}, \mathbf{d})$, sea surface temperature $\left({ }^{\circ} \mathrm{C} ; \mathbf{e}, \mathbf{f}\right)$ and sea surface salinity (PSU; $\left.\mathbf{g}, \mathbf{h}\right)$.

Denmark Strait and the Canadian Arctic Archipelago freshen and cool the NWA and help to trigger and maintain the cold state with a fresh and cold NWA without deep convection.

As mentioned above, we found one additional event when the NAO exceeded the $2 \sigma$ interval for more than 10 years (7861-7874 BP) with SST and SSS anomalies of up to $-0.7^{\circ} \mathrm{C}$ and -0.13 PSU in the NWA (Fig. 2). Apart from the fact that the anomalies are smaller and that the sea ice cover did not expand over the NWA, their spatial patterns show large similarities to the two cold events discussed in this paper (not shown; Fig. 6). Furthermore, the freshwater transport anomalies through the Denmark Strait and the Canadian Arctic Archipelago reached -672 and $+328 \mathrm{~km}^{3} \mathrm{yr}^{-1}$ for a net transport anomaly of only $-343 \mathrm{~km}^{3} \mathrm{yr}^{-1}$ (not shown) compared to the anomalous net transports of about
$-700 \mathrm{~km}^{3} \mathrm{yr}^{-1}$ for the two cold events. The positive NAO phase during the early Holocene interval 7861-7874 BP was too short to induce sufficient freshening in the NWA and hence did not cause an abrupt cold event. In conclusion, the SSS anomaly of $\sim 0.5$ PSU during the two cold events is enough to affect NWA deep convection and create a cold event, whereas lower SSS anomalies during other periods are not enough to affect deep convection significantly. Given the size of the NWA area, its mean mixed-layer depth and the SSS anomaly required for convection to stop ( $\sim 0.5 \mathrm{PSU})$, we can very roughly estimate that the corresponding salt deficit is on the order of $150 \mathrm{Gt}$. For reference, a salt anomaly of about $78 \mathrm{Gt}$ was estimated for the Great Salinity Anomaly (Dickson et al., 1988). We suggest that there exists a threshold in SSS that can be exceeded after $\sim 20$ years of anoma- 
(a)

Event 1

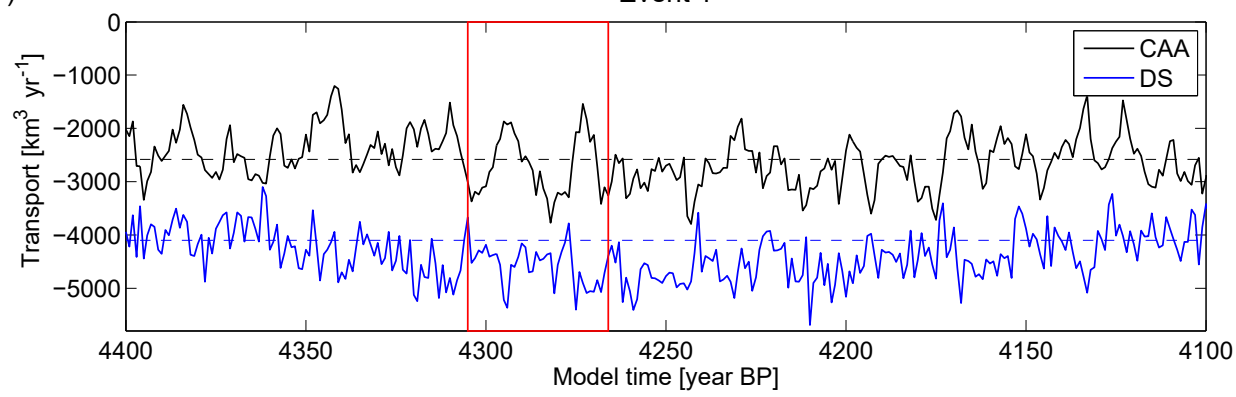

(b)

Event 2

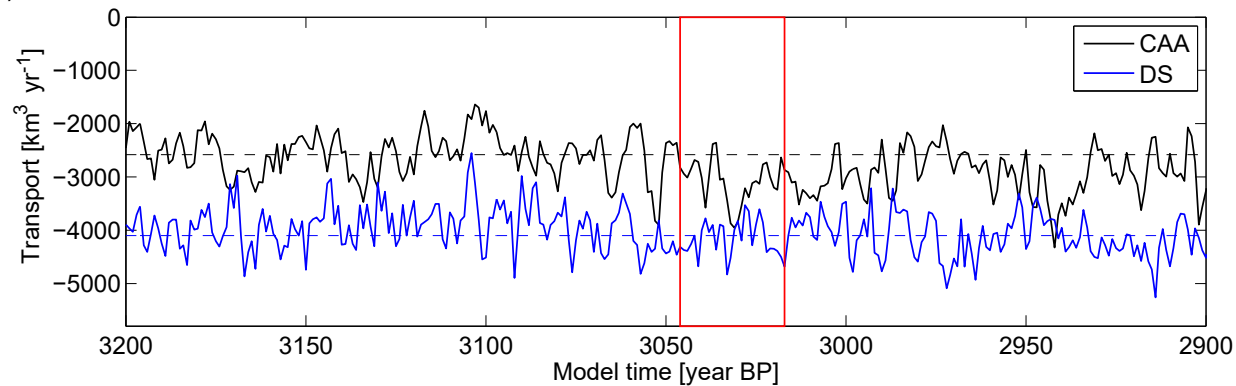

Figure 7. Freshwater flux through the Canadian Arctic Archipelago (CAA; black) and the Denmark Strait (DS; blue) with a reference salinity of 34.7 PSU during (a) event 1 and (b) event 2. Negative values correspond to a southward transport. The red boxes indicate the time span of the events. The dashed lines represent the corresponding mean over the entire time span of the simulation.
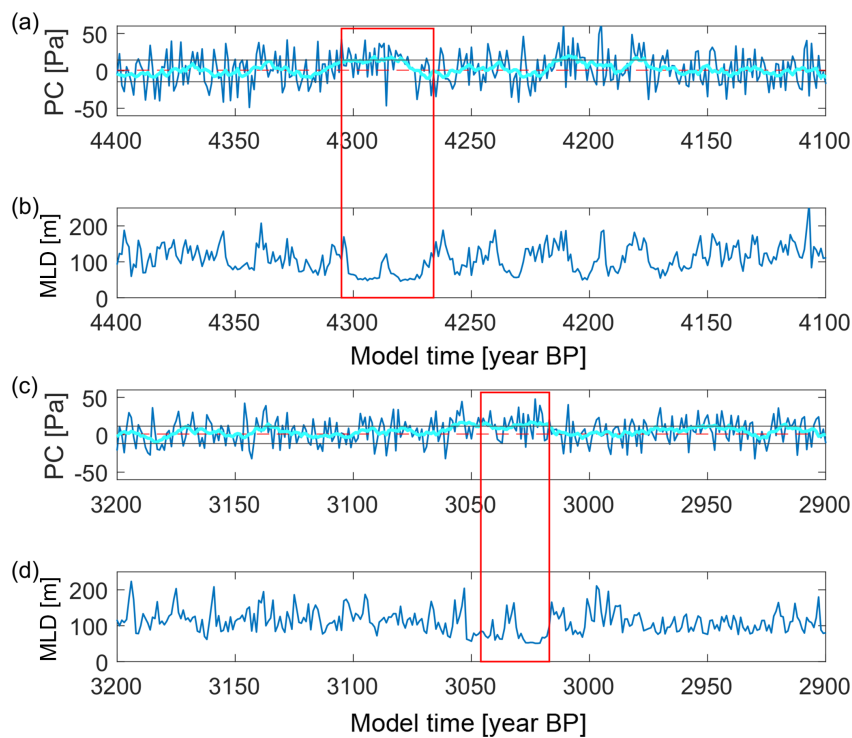

Figure 8. Leading principal component (PC) of the sea-level pressure over the Atlantic sector north of $35^{\circ} \mathrm{N}$ for (a) event 1 during winter (DJF) and (c) event 2 during spring (MAM). The respective 10-year-running means are indicated by the light blue lines. Annual mixed-layer depth (MLD) for event 1 (b) and event 2 (d) are shown. The red boxes indicate the time span of the events. The gray lines in (a) and (c) indicate the $2 \sigma$ interval of the 10-year-running means of the corresponding PC. lous atmospheric forcing and freshwater transports in the North Atlantic as well as through the Denmark Strait and the Canadian Arctic Archipelago, and which affects deep convection in the North Atlantic.

Moreno-Chamarro et al. $(2015,2017)$ present cold events in the North Atlantic in climate simulations and climate reconstructions that are generated by internal variability and modulated by external forcing. The events involve weakening of the SPG, followed by surface freshening, cooling, and shutdown of deep convection, but no significant weakening of the AMOC, similar to our cold events. Similar to MorenoChamarro et al. (2017) we also found anomalous freshwater transport from the Arctic prior to and during the events, but in disagreement with them, we found a key role for the NAO in triggering the events.

Another possible mechanism explaining cold events in the North Atlantic region is discussed by Lehner et al. (2013). In an ensemble of transient simulations from the Medieval Climate Anomaly to the Little Ice Age they used artificial sea ice growth as a sensitivity parameter. The sea ice is then transported to the subpolar North Atlantic, melts, and reduces the deep-water formation and therefore the AMOC. Due to the reduced northward heat transport sea ice can expand and the northern North Atlantic and Nordic Seas cool further. The authors suggest that the sea ice transport is supported by increasing SLP above the Barents Sea but not by a NAO anomaly. This mechanism hence differs from the mechanism presented here, where a NAO anomaly triggers changes in 
(a) SSS and top 100 m ocean circulation

$60^{\circ}$

$30^{\circ} \mathrm{N}$

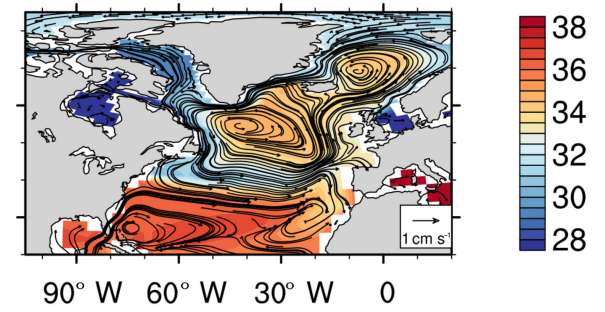

(b)

Anomalies during event 1

$60^{\circ} \mathrm{N}$

$30^{\circ} \mathrm{N}$

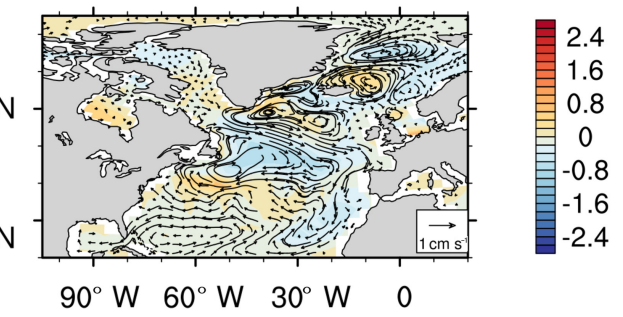

(c)

\section{Anomalies during event 2}

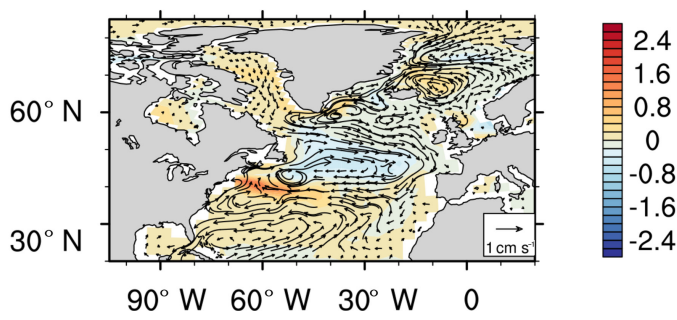

et al., 2012). A detailed description of this cold oscillatory mode in a low-resolution version of the CCSM3 was presented by Yoshimori et al. (2010). They presented the quasidecadal oscillations as a feature of a cold climate mode with a weak AMOC. Furthermore, in the experiments by Stocker et al. (2007) one can see a similar oscillatory behavior for the AMOC. Therefore, we suggest that the oscillatory behavior during the events indicates a nearby tipping point towards the same cold mode.

\subsection{AMOC and reduced deep-water formation}

The AMOC time series does not undergo a climate transition to a weak state during the events (Figs. 4-5), although the mixed-layer depth in the NWA decreases during these periods. The increasing mixed-layer depths northeast of Iceland during the events seem to compensate for the decreased mixed-layer depths in the northern Nordic Seas and the NWA (Fig. 6a-b) keeping the AMOC in a strong state. Deep convection, however, does not occur in the Labrador Sea where it would be expected (Kuhlbrodt et al., 2007), but is shifted towards the east, south of Greenland. In accord with other simulations using the CCSM (Prange, 2008; Gnanadesikan et al., 2006) a negative bias in surface salinity in the Labrador Sea could explain this spatial shift.

In disagreement with other modeling studies in which a positive NAO leads to a cooling and density increase of the upper ocean layer in the northern North Atlantic (Delworth and Dixon, 2000; Häkkinen, 1999), the positive NAO phase during our events is neither accompanied by an intensification of deep convection in the Labrador Sea/NWA nor the AMOC. In our study, the freshening of the NWA results in a decrease in density and the extreme cooling of up to $-4{ }^{\circ} \mathrm{C}$ results in an SST close to the freezing point. Consequently, the fresh and ice covered water column becomes stable and deep convection breaks down (Figs. 2, 4-5). A short phase of a positive NAO leads to changes in turbulent surface fluxes (fast processes) while a persistent positive NAO phase over decades, as in our study, can change the ocean freshwater transports (slow processes). The forcing is the same (positive NAO) but the consequences depend on the duration of the freshwater transport anomaly. Furthermore, a severe weakening of deep convection, such as in our study, is often accompanied by a mode switch of the AMOC (Drijfhout et al., 2013; Schulz et al., 2007). In our study, the area of deep-water formation in the NWA cools substantially, while the AMOC weakens by only $1.5 \mathrm{~Sv}(0.6 \mathrm{~Sv})$ during event 1 (event 2). These results are in accord with results from Born and Levermann (2010) who showed an abrupt transition in the North Atlantic due to a freshwater input of $160 \times 10^{12} \mathrm{~m}^{3}$ within 2 years to the coast of the Labrador Sea, while the AMOC just weakens by $1.5 \mathrm{~Sv}$ and recovers after approximately 100 years. et al., 2012). Hence, relatively short atmospheric anomalies can serve as a driving mechanism for climate fluctuations on longer timescales ("noise-induced tipping"; Ashwin 


\subsection{Link to drift-ice events}

The stronger and northward-shifted westerlies due to a positive NAO can transport sea ice from the NWA farther across the northern North Atlantic until almost west of Ireland (4295 BP; Figs. 4a, c, 5a, c). A comparable sea ice extent has been discussed by Bond et al. (2001) based on ice-rafted debris. The authors stated that the sea ice in their study was probably transported by surface waters from north of Iceland towards the coring side MC-VM-29-191 west of Ireland. An atmospheric change representing a positive NAO-like state as in our study could have been the trigger for the events discussed in Bond et al. (2001). The authors also suggest that a decrease in SST and SSS during drift-ice events potentially led to a reduced deep-water formation in the North Atlantic and therefore a reduced thermohaline circulation. We suspect that an increase in sea ice concentration in the southern Nordic Seas, unlike in our study, could possibly weaken the deep-water formation there as well, such that its compensating effect on the reduced NWA deep-water formation would vanish, causing the AMOC to collapse as suggested by Bond et al. (2001).

\section{Summary and conclusions}

Two abrupt cold events that last for 39 and 29 years have been detected in the northern North Atlantic during a 7000-year Holocene model run. The events were initiated by a positive NAO phase and the associated wind anomalies, inducing chances in ocean circulation and freshwater transports in the subpolar seas. The freshwater transport through the Denmark Strait (event 1) and Canadian Arctic Archipelago (event 2) intensified leading to a freshening of the surface ocean in the deep convection area of the northwest Atlantic and an increase in the water column stability. The events are characterized by a cooling, freshening, and weakening of the SPG and a severe sea ice advance maintaining a circulation state without deep convection in the NWA. We suggest that the oceanatmosphere coupling (SST anomaly tripole forces a positive NAO-like state and vice versa) and the increased freshwater transports through the Denmark Strait and the Canadian Arctic Archipelago helped to maintain the cold state for decades. A return to normal NAO atmospheric conditions heralds the termination of the cold events.

Atmospheric variability plays a key role in the development of the cold events and the associated changes in ocean circulation. This suggests that atmospheric anomalies (e.g., like a persistent positive NAO phase) may have led to climate transitions in the past and that similar processes may also be a major trigger for future climate variability. An important component that needs to be considered in this context is the extent of the sea ice. Sea ice affects the ocean-atmosphere interaction, thereby amplifying the cold events. Due to climate warming, the sea ice concentration in the Arctic realm massively decreases, leading to an increase in the freshwa- ter content of the northern North Atlantic due to melting sea ice, which would render the ocean more sensitive to an atmospheric trigger stopping the deep-water formation. On the other hand, sea ice is less likely to reach areas of deep-water formation in a warmer climate. As a result, the potential of a stochastic atmospheric anomaly to trigger an abrupt cold event may be modified by the changing North Atlantic background climate under increasing greenhouse gas emissions, which may further complicate the investigation and projection of abrupt climate change.

Data availability. Model results with CCSM3 presented in this study will be uploaded to the PANGAEA database: https://doi. pangaea.de/10.1594/PANGAEA.892966 (Klus et al., 2018).

Competing interests. The authors declare that they have no conflict of interest.

Acknowledgements. This project was supported by the Deutsche Forschungsgemeinschaft (DFG) through the International Research Training Group "Processes and impacts of climate change in the North Atlantic Ocean and the Canadian Arctic" (IRTG 1904 ArcTrain). The authors would like to thank Ute Merkel for making the spun-up pre-industrial control run restart files available. We are very grateful to Christoph Raible for his helpful and constructive comments. The CCSM3 experiments were performed with resources provided by the North-German Supercomputing Alliance (HLRN).

The article processing charges for this open-access publication were covered by the University of Bremen.

Edited by: Dominik Fleitmann

Reviewed by: Christoph C. Raible

\section{References}

Aagaard, K. and Carmack, E. C.: The role of sea ice and other fresh water in the Arctic circulation, J. Geophys. Res., 94, 14484$14498,1989$.

Alley, R. B. and Ágústsdóttir, A. M.: The $8 \mathrm{k}$ event: cause and consequences of a major Holocene abrupt climate change, Quaternary Sci. Rev., 24, 1123-1149, https://doi.org/10.1016/j.quascirev.2004.12.004, 2005.

Ashwin, P., Wieczorek, S., Vitolo, R., and Cox, P.: Tipping points in open systems: bifurcation, noise-induced and rate-dependent examples in the climate system, Phil. T. R. Soc. A, 370, 11661184, https://doi.org/10.1098/rsta.2011.0306, 2012.

Belt, S. T., Massé, G., Poulin, M., LeBlanc, B., Michel, C., and Rowland, S.: A novel chemical fossil of palaeo sea ice: IP25, Org. Geochem., 38, 16-27, 2007.

Bond, G., Showers, W., Cheseby, M., Lotti, R., Almasi, P., deMenocal, P., Priore, P., Cullen, H., Hajdas, I., and Bonani, G.: 
A pervasive millennial-scale cycle in North Atlantic Holocene and glacial climates, Science, 28, 1257-1266, 1997.

Bond, G., Kromer, B., Beer, J., Muscheler, R., Evans, M., Showers, W., Hoffmann, S., Lotti-Bond, R., Hajdas, I., and Bonani, G.: Persistent Solar Influence on North Atlantic Climate During the Holocene, Science, 294, 2130-2136, 2001.

Born, A. and Levermann, A.: The $8.2 \mathrm{ka}$ event: Abrupt transition of the subpolar gyre toward a modern North Atlantic circulation, Geochem. Geophy. Geosy., 11, Q06011, https://doi.org/10.1029/2009GC003024, 2010.

Braconnot, P., Otto-Bliesner, B., Harrison, S., Joussaume, S., Peterchmitt, J.-Y., Abe-Ouchi, A., Crucifix, M., Driesschaert, E., Fichefet, Th., Hewitt, C. D., Kageyama, M., Kitoh, A., Laîné, A., Loutre, M.-F., Marti, O., Merkel, U., Ramstein, G., Valdes, P., Weber, S. L., Yu, Y., and Zhao, Y.: Results of PMIP2 coupled simulations of the Mid-Holocene and Last Glacial Maximum Part 1: experiments and large-scale features, Clim. Past, 3, 261277, https://doi.org/10.5194/cp-3-261-2007, 2007.

Briegleb, B. P., Bitz, C. M., Hunke, E. C., Lipscomb, W. H., Holland, M. M., Schramm, J. L., and Moritz, R. E.: Scientific description of the sea-ice component in the Community Climate System Model, Version Three. Tech., NCAR/TN-463STR, National Center for Atmospheric Research, Boulder, CO, 70 pp., 2004.

Büntgen, U., Tegel, W., Nicolussi, K., McCormick, M., Frank, D., Trouet, V., Kaplan, J. O., Herzig, F., Heusser, K.-U., Wanner, H., Luterbacher, J., and Esper, J.: 2500 Years of European Climate Variability and Human Suscepility, Science, 331, 578-582, https://doi.org/10.1126/science.1197175, 2011.

Camenisch, C., Keller, K. M., Salvisberg, M., Amann, B., Bauch, M., Blumer, S., Brázdil, R., Brönnimann, S., Büntgen, U., Campbell, B. M. S., Fernández-Donado, L., Fleitmann, D., Glaser, R., González-Rouco, F., Grosjean, M., Hoffmann, R. C., Huhtamaa, H., Joos, F., Kiss, A., Kotyza, O., Lehner, F., Luterbacher, J., Maughan, N., Neukom, R., Novy, T., Pribyl, K., Raible, C. C., Riemann, D., Schuh, M., Slavin, P., Werner, J. P., and Wetter, O.: The 1430s: a cold period of extraordinary internal climate variability during the early Spörer Minimum with social and economic impacts in north-western and central Europe, Clim. Past, 12, 2107-2126, https://doi.org/10.5194/cp-12-2107-2016, 2016.

Collins, W. D., Bitz, C. M., Blackmon, M. L., Bonan, G. B., Bretherton, C. S., Carton, J. A., Chang, P., Doney, S. C., Hack, J. J., Henderson, T. B., Kiehl, J. T., Large, W. G., McKenna, D. S., Santer, B. D., and Smith, R. D.: The community climate system model version (CCSM3), J. Clim., 19, 2122-2143, 2006a.

Collins, W. D., Rasch, P. J., Boville, B. A., Hack, J. J., McCaa, J. R., Williamson, D. I., and Briegleb, B. P.: The formulation and atmospheric simulation of the Community Atmosphere Model version 3 (CAM3), J. Clim., 19, 2144-2161, https://doi.org/10.1175/JCLI3760.1, 2006b.

Crowley, T. J.: Causes of Climate Change Over the Past 1000 Years, Science, 289, 270-277, https://doi.org/10.1126/science.289.5477.270, 2000.

Crowley, T. J. and Lowery, T. S.: How warm was the Medieval Warm Period?, Ambio, 29, 51- 54, 2000.

Czaja, A. and Frankignoul, C.: Observed Impact of Atlantic SST Anomalies on the North Atlantic Oscillation, J. Clim., 15, 606623, 2002.
Delworth, T. and Dixon, K.: Implications of the recent trend in the Arctic/North Atlantic oscillation for the North Atlantic thermohaline circulation, J. Clim., 13, 3721-3727, https://doi.org/10.1175/15200442(2000)013<3721:IOTRTI>2.0.CO;2, 2000.

Deser, C., Alexander, M. A., Xie, S.-P., and Phillips, A. S.: Sea Surface Temperature Variability: Patterns and Mechanisms, Annu. Rev. Mar. Sci., 2, 115-143, https://doi.org/10.1146/annurevmarine-120408-151453, 2010.

Dickson, R., Rudels, B., Dye, S., Karcher, M., Meincke, J., and Yashayaev, I.: Current estimates of freshwater flux through Arctic and subarctic seas, Prog. Oceanogr., 73, 210-230, https://doi.org/10.1016/j.pocean.2006.12.003, 2007.

Dickson, R. R., Meincke, J., Malmberg, S.-A., and Lee, A.: The "great salinity anomaly" in the Northern North Atlantic 19681982, Prog. Ocean., 20, 103-151, https://doi.org/10.1016/00796611(88)90049-3, 1988.

Drijfhout, S. E., Gleeson, H. A., Dijkstra, H. A., and Livina, V.: Spontaneous abrupt climate change due to an atmospheric blocking-sea-ice-ocean feedback in an unforced climate model simulation, P. Natl. Acad. Sci. USA, 110, 19713-1971, https://doi.org/10.1073/pnas.1304912110, 2013.

Frankignoul, C. and Gastineau, G.: Wintertime Atmospheric Response to North Atlantic Ocean Circulation Variability in a Climate Model, J. Clim., 28, 7659-7677, https://doi.org/10.1175/JCLI-D-15-0007.1, 2015.

Gastineau, G. and Frankignoul, C.: Influence of the North Atlantic SST Variability on the Atmospheric Circulation during the Twentieth Century, J. Clim., 28, 1396-1416, https://doi.org/10.1175/JCLI-D-14-00424.1, 2014.

Gnanadesikan, A., Dixon, K. W., Griffies, S. M., Balaji, V., Barreiro, V., Beesley, J. A., Cooke, W. F., Delworth, T. L., Gerdes, R., Harrison, M. J., Held, I. M., Hurlin, W. J., Lee, H.-C., Liang, Z., Nong, G., Pacanowski, R. C., Rosati, A., Russel, J., Samuels, B. L., Song, Q., Spelman, M. J., Stouffer, R. J., Sweeney, C. O., Vecchi, G., Winton, M., Wittenberg, A. T., Zeng, F., Zhang, R., and Dunne, J. P.: GFDL's CM2 global coupled climate models-Part 2: The baseline ocean simulation, J. Clim., 19, 675697, 2006.

Gray, L. J., Beer, J., Geller, M., Haigh, J. D., Lockwood, M., Matthes, K., Cubasch, U., Fleitmann, D., Harrison, G., Hood, L., Luterbacher, J., Meehl, G. A., Shindell, D., van Geel, B., and White, W.: Solar influence on climate, Rev. Geophys., 48, RG4001, https://doi.org/10.1029/2009RG000282, 2010.

Hall, A. and Stouffer, R. J.: An abrupt climate event in a coupled ocean-atmosphere simulation without external forcing, Nature, 409, 171-174, 2001.

Hall, I. R., Bianchi, G. G., and Evans, J. R.: Centennial to millennial scale Holocene climate-deep water linkage in the North Atlantic, Quaternary Sci. Rev., 23, 1529-1536, 2004.

Häkkinen, S.: Variability of the simulated meridional heat transport in the North Atlantic for the period 1951-1993, J. Geophys. Res., 104, 10991-11008, https://doi.org/10.1029/1999JC900034, 1999.

Hasselmann, K.: Stochastic climate models, I. Theory, Tellus, 28, 473-485, https://doi.org/10.1111/j.2153-3490.1976.tb00696.x, 1976.

Hawkins, E., Smith, R. S., Allison, L. C., Gregory, J. M., Woolings, T. J., Pohlmann, H., and de Cuevas, B.: Bistability of the At- 
lantic overturning circulation in a global climate model and links to ocean freshwater transport, Geophys. Res. Lett., 38, L10605, https://doi.org/10.1029/2011GL047208, 2011.

Hurrell, J. W., Kushnir, Y., Ottersen, G., and Visbeck, M.: An Overview of the North Atlantic Oscillation, Geophysical Monograph 134, American Geophysical Union, Washington, DC, 135, https://doi.org/10.1029/134GM01, 2013.

Ionita, M., Scholz, P., Lohmann, G., Dima, M., and Prange, M.: Linkages between atmospheric blocking, sea ice export through Fram Strait and the Atlantic Meridional Overturning Circulation, Sci. Rep., 6, 32881, https://doi.org/10.1038/srep32881, 2016.

Jahn, A., Tremblay, L. B., Newton, R., Holland, M. M., Mysak, L. A., and Dmitrenko, I. A.: A tracer study of the Arctic Ocean's liquid freshwater export variability, J. Geophys. Res., 115, C07015, https://doi.org/10.1029/2009JC005873, 2010.

Jiang, H., Eiriksson, J., Schulz, M., Knudsen K.-L., and Seidenkrantz, M. S.: Evidence for solar forcing of sea-surface temperature on the North Icelandic shelf during the late Holocene, Geology, 33, 73-76, https://doi.org/10.1130/G21130.1, 2005.

Jongma, J. I., Prange, M., Renssen, H., and Schulz, M.: Amplification of Holocene multicentennial climate forcing by mode transitions in North Atlantic overturning circulation, Geophys. Res. Lett., 34, L15706, https://doi.org/10.1029/2007GL030642, 2007.

Karcher, M., Gerdes, R., Kauker, F., Köberle, C., and Yashayaev, I.: Arctic Ocean change heralds North Atlantic freshening, Geophys. Res. Lett., 32, L21606, https://doi.org/10.1029/2005GL023861, 2005.

Kleppin, H., Jochum, M., Otto-Bliesner, B., Shields, C. A., and Yeager, S.: Stochastic Atmospheric Forcing as a Cause of Greenland Climate Transitions, J. Clim., 28, 7741-7763, https://doi.org/10.1175/JCLI-D-14-00728.1, 2015.

Klus, A., Prange, M., Varma, V., Tremblay, L. B., and Schulz, M.: Investigation of abrupt cold events in the North Atlantic Ocean in a transient Holocene simulation, PANGAEA, https://doi.org/10.1594/PANGAEA.892966, 2018.

Kuhlbrodt, T., Griesel, A., Montoya, M., Levermann,. A,, Hofmann, M., and Rahmstorf, S.: On the driving processes of the Atlantic Meridional Overturning Circulation, Rev. Geophys., 45, RG2001, https://doi.org/10.1029/2004RG000166, 2007.

Kwok, R.: Recent Changes in Arctic Ocean Sea Ice Motion Associated with the North Atlantic Oscillation, Geophys. Res. Lett., 27, 775-778, 2000.

Lehner, F., Born, A., Raible, C. C., and Stocker, T. F.: Amplified inception of European Little Ice Age by sea ice-ocean-atmosphere feedbacks, J. Clim., 26, 7586-7602, 2013.

Levermann, A. and Born, A.: Bistability of the Atlantic subpolar gyre in a coarse-resolution climate model, Geophys. Res. Lett., 34, L24605, https://doi.org/10.1029/2007GL031732, 2007.

Li, C., Battisti, D. S., Schrag, D. P., and Tziperman, E.: Abrupt climate shifts in Greenland due to displacements of the sea-ice edge, Geophys. Res. Lett., 32, L19702, https://doi.org/10.1029/2005GL023492, 2005.

Li, C. and Bitz, C. M.: Can North Atlantic sea-ice anomalies account for Dansgaard-Oeschger climate signals?, J. Clim., 23, 5457-5475, https://doi.org/10.1175/2010JCLI3409.1, 2010.

Lohmann, K., Drange, H., and Bentsen, M.: Response of the North Atlantic subpolar gyre to persistent North Atlantic oscillation like forcing, Clim. Dynam., 32, 273-285, https://doi.org/10.1007/s00382-008-0467-6, 2008.
Massè, G., Rowland, S. J., Sicre, M.-A., Jacob, J., Jansen, E., and Belt, S. T.: Abrupt climate changes for Iceland during the last millennium: Evidence from high resolution seaice reconstructions, Earth Planet. Sc. Lett., 269, 565-569, https://doi.org/10.1016/j.eps1.2008.03.017, 2008.

Merkel, U., Prange, M., and Schulz, M.: ENSO variability and teleconnections during glacial climates, Quaternary Sci. Rev., 29, 86-100, https://doi.org/10.1016/j.quascirev.2009.11.006, 2010.

Moreno-Chamarro, E., Zanchettin, D., Lohmann, K., and Jungclaus, J. H.: Internally generated decadal cold events in the northern North Atlantic and their possible implications for the demise of the Norse settlements in Greenland, Geophys. Res. Lett., 42, 908-915, 2015.

Moreno-Chamarro, E., Zanchettin, D., Lohmann, K., and Jungclaus, J. H.: An abrupt weakening of the subpolar gyre as trigger of Little Ice Age-type episodes, Clim. Dynam., 48, 721-744, https://doi.org/10.1007/s00382-016-3106-7, 2017.

O’Brien, S. R., Mayewski, P. A., Meeker, L. D., Meese, D. A., Twickler, M. S., and Whitlow, S. I.: Complexity of Holocene climate as reconstructed from a Greenland ice core, Science, 270, 1962-1694, https://doi.org/10.1126/science.270.5244.1962, 1995.

Oka, A., Hasumi, H., Okada, N., Sakamoto, T. T., and Suzuki, T.: Deep convection seesaw controlled by freshwater transport through Denmark Strait, Ocean Modell., 15, 157-176, https://doi.org/10.1016/j.ocemod.2006.08.004, 2006.

Ortega, P., Lehner, F., Swingedouw, D., Masson-Delmotte, V., Raible, C. C., Casado, M., and Yiou, P.: A model-tested NorthAtlantic Oscillation reconstruction for the last millennium, Nature, 523, 71-75, 2015.

Prange, M.: The low-resolution CCSM2 revisited: new adjustments and a present-day control run, Ocean Sci., 4, 151-181, https://doi.org/10.5194/os-4-151-2008, 2008.

Prange, M. and Gerdes, R.: The role of surface freshwater flux boundary conditions in Arctic Ocean modelling, Ocean Modell., 13, 25-43, 2006.

Rahmstorf, S.: On the freshwater forcing and transport of the Atlantic thermohaline circulation, Clim. Dynam., 12, 799-811, https://doi.org/10.1007/s003820050144, 1996.

Raible, C. C., Lehner, F., González-Rouco, J. F., and FernándezDonado, L.: Changing correlation structures of the Northern Hemisphere atmospheric circulation from 1000 to 2100 AD, Clim. Past, 10, 537-550, https://doi.org/10.5194/cp-10-5372014, 2014.

Scheffer, M., Bascompte, J., Brock, W. A., Brovkin, V., Carpenter, S. R., Dakos, V., Held, H., van Nes, E. H., Rietkerk, M., and Sugihara, G.: Early-warning signals for critical transitions, Nature, 461, 7260, https://doi.org/10.1038/nature08227, 2009.

Schmutz, C., Luterbacher, J., Gyalistras, D., Xoplaki, E., and Wanner, H.: Can we trust proxy-based NAO index reconstructions?, Geophys. Res. Lett., 27, 1135-1138, 2000.

Schulz, M. and Paul, A.: Holocene climate variability on centennialto-millennial time scales: 1. Climate records from the NorthAtlantic realm, in: Climate development and history of the North Atlantic Realm, edited by: Wefer, G., Berger, W. H., Behre, K.-E., and Jansen, E., Springer Verlag, Berlin, 41-54, https://doi.org/10.1007/978-3-662-04965-5_4, 2002.

Schulz, M., Prange, M., and Klocker, A.: Low-frequency oscillations of the Atlantic Ocean meridional overturning cir- 
culation in a coupled climate model, Clim. Past, 3, 97-107, https://doi.org/10.5194/cp-3-97-2007, 2007.

Sigl, M., Winstrup, M., McConnell, J. R., Welten, K. C., Plunkett, G., Ludlow, F., Büntgen, U., Caffee, M., Chellman, N., Dahl-Jensen, D., Fischer, H., Kipfstuhl, S., Kostick, C., Maselli, O. J., Mekhaldi, F., Mulvaney, R., Muscheler, R., Pasteris, D. R., Pilcher, J. R., Salzer, M., Schüpbach, S., Steffensen, J. P., Vinther, B. M., and Woodruff, T. E.: Timing and climate forcing of volcanic eruptions for the past 2,500 year, Nature, 523, 543-549, https://doi.org/10.1038/nature14565, 2015.

Smith, R. and Gent, P.: Ocean component of the Community Climate System model (CCSM2.0 and 3.0), Reference manual for the Parallel Ocean Program (POP), 2004.

Steinhilber, F., Beer, J., and Fröhlich, C.: Total solar irradiance during the Holocene, Geophys. Res. Lett., 36, L19704, https://doi.org/10.1029/2009GL040142, 2009.

Stocker, T. F., Timmermann, A., Renold, M., and Timm, O.: Effects of salt compensation on the climate model response in simulations of large changes of the Atlantic meridional overturning circulation, J. Clim., 20, 5912-5928, 2007.

Varma, V., Prange, M., and Schulz, M.: Transient simulations of the present and the last interglacial climate using the Community Climate System Model version 3: effects of orbital acceleration, Geosci. Model Dev., 9, 3859-3873, https://doi.org/10.5194/gmd9-3859-2016, 2016.

Visbeck, M., Chassignet, E., Curry, R., Delworth, T., Dickson, B., and Krahmann, G.: The ocean's response to North Atlantic oscillation variability, in: The North Atlantic oscillation, edited by: Hurrell, J., Kushnir, Y., Ottersen, G., and Visbeck, M., AGU Monograph 134, American Geophysical Union, Washington, DC, 2003.
Wanner, H., Pfister, C., Brázdil, R., Frich, P., Frydendahl, K., Jónsson, T., Kington, J., Lamb, H. H., Rosenørn, S., and Wishman, E.: Wintertime European Circulation Patterns During the Late Maunder Minimum Cooling Period (1675-1704), Theor. Appl. Climatol., 51, 167-175, 1995.

Wanner, H., Brönnimann, S., Casty, C., Luterbacher, J., Schmutz, C., and David, B.: North Atlantic OscillationConcepts and Studies, Surv. Geophys., 22, 1791-1828, https://doi.org/10.1023/A:1014217317898, 2001.

Wanner, H., Beer, J., Bültikofer, J., Crowley, T. J., Cubasch, U., Flückiger, J., Goosse, H., Grosjean, M., Joos, F., Kaplan, J. O., Küttel, M., Prentice, I. C., Solomina, O., Stocker, T. F., Tarasov, P., Wagner, M., and Widmann, M.: Mid- to Late Holocene climate change: an overview, Quaternary Sci. Rev., 27, 1791-1828, https://doi.org/10.1016/j.quascirev.2008.06.013, 2008.

Wanner, H., Solomina, O., Grosjean, M., Ritz, S. P., and Jetel, M.: Structure and origin of Holocene cold events, Quaternary Sci. Rev., 30, 21-22, https://doi.org/10.1016/j.quascirev.2011.07.010, 2011.

Yeager, S. G., Shields, C. A., Large, W. G., and Hack, J. J.: The low-resolution CCSM3, J. Clim., 19, 2545-256, 2006.

Yoshimori, M., Raible, C. C., Stocker, T. F., and Renold, M.: Simulated decadal oscillations of the Atlantic meridional overturning circulation in a cold climate state, Clim. Dynam., 34, 101-121, https://doi.org/10.1007/s00382-009-0540-9, 2010. 